\title{
Green Synthesis of Carbon Nanotubes from Coconut Shell Waste for Pb(II) Ion Adsorption
}

\author{
Yusuf Zaim Hakim*, Yoki Yulizar, Adi Nurcahyo, Magun Surya \\ Department of Chemistry, Faculty of Mathematics and Natural Sciences, Universitas Indonesia. \\ Kampus UI Depok, 16424 Indonesia \\ ${ }^{*}$ Corresponding author. Email address: yusuf.zaim@alumni.ui.ac.id
}

Received July 20, 2017; Accepted December 4, 2017

\begin{abstract}
Numerous complex methods have been developed for the preparation of carbon nanotubes (CNT) such as laser vaporization, arc discharge, pyrolysis, and chemical vapour deposition (CVD). In this study, an environmentally friendly and convenient method called one-step water assisted (quenching) synthesis method was conducted from graphite flakes, which were taken from coconut shell wastes to produce carbon nanotubes. Chemical and physical structure of the carbon nanotubes were characterized by FTIR (Fourier Transform Infrared), Scanning Electron Microscope (SEM), and Transmission Electron Microscopy (TEM). Adsorption performance of heavy metals $\mathrm{Pb}(\mathrm{II})$ ions by CNTs has been evaluated using the stirring method, and the concentration of $\mathrm{Pb}$ (II) ions has been determined using Atomic Absorption Spectroscopy (AAS). The adsorption conditions such as $\mathrm{pH}$ and contact time have been obtained. The results showed that carbon nanotubes were a bit successfully formed, in which the tubes distribution are scattered irregularly. The average tube diameter was $123 \mathrm{~nm}$. During the adsorption test, it was found that the adsorption was proportional to the contact time, in which the optimum contact time was 20 minutes. The optimum $\mathrm{pH}$ of $\mathrm{Pb}$ (II) ions absorption was 5 where the potential for $\mathrm{Pb}(\mathrm{II})$ ions absorption was $120 \%$. The results indicate the true potential of this green chemistry based method, and it opens the chance for possibility to produce carbon nanotubes at a larger scale.
\end{abstract}

Key words: graphite, quenching, carbon nanotubes, adsorption, $\mathrm{Pb}(\mathrm{II})$ ions.

\section{ABSTRAK}

Berbagai metode rumit telah dikembangkan untuk membuat carbon nanotubes (CNTs) seperti ablasi laser, pancaran elektroda, pirolisis, dan deposisi penguapan kimia. Pada penelitian ini, metode sintesis carbon nanotubes yang mudah dan ramah lingkungan yaitu one step water assisted (pemadaman) telah dilakukan dari serpihan grafit yang berasal dari limbah tempurung kelapa. Karakterisasi kimia dan fisika dari carbon nanotubes yang dihasilkan dilakukan dengan instrument FTIR (Fourier Transform Infared), Scanning Electron Microscope (SEM), dan Transmission Electron Microscopy (TEM). Kinerja adsorpsi terhadap ion logam berat $\mathrm{Pb}(\mathrm{II})$ telah diukur menggunakan Atomic Absorption Spectroscopy (AAS) pada kondisi pH dan waktu kontak yang bervariasi. Hasil menunjukkan nanotubes carbon sedikit terbentuk, dimana distribusi tubes tersebar secara tidak beraturam. Rata-rata diameter tube adalah $123 \mathrm{~nm}$. Hasil uji adsorpsi menunjukkan bahwa adsorpsi sebanding dengan waktu kontak, dengan waktu kontak optimum pada 20 menit. $\mathrm{pH}$ optimum penyerapan logam berat $\mathrm{pH}$ ditemukan pada $\mathrm{pH} 5$, sama dengan nilai $\mathrm{pH}$ pada studi sebelumnya, dengan maksimum persen teradsorpsi mencapai $120 \%$. Hasil ini menunjukkan potensi dari metode sintesis berbasis green chemistry, dan membuka peluang kemungkinan produksi carbon nanotubes dalam skala yang lebih besar.

Kata kunci: grafit, pemadan, carbon nanotubes, adsorpsi, ion $\mathrm{Pb}(\mathrm{II})$.

\section{INTRODUCTION}

The release of heavy metal waste into the ecosystem due to rapid industrial development has shifted the world's attention in recent years. Liquid pollutants from many industries such as metallurgical, chemical manufacturing, mining, industries, etc. contain one or more toxic metal ions. Lead $(\mathrm{Pb})$ are known to be quite alarming waste due to its toxic properties for living organisms. Adsorption method is one of the promising solution that is often used in solving the problems because the employed adsorbent can be regenerated by suitable desorption process and it is highly effective and economical [1]. There were a lot of material that has been proved to act as lead metal ion adsorbent such as activated carbon [2], zeolites [3], and kaolin [4]. However, these adsorbents have a low 
adsorption capacity to interact with ions of heavy metals [1]. Therefore, researchers carried out other investigation for new promising adsorbents.

Carbon Nanotubes is a current growing nanomaterial that is widely getting more attention from researchers because of extensive utilization in creating new technologies in the field of chemistry, electronics, health, biotechnology, and the environment. Since discovered by ljima in 1991 [5], CNT became the focus of the research object of various circles due to its unique structural, electronic, optoelectronic, semiconductor, mechanical, chemical, and physical properties [6]. Some of these characters is its inert surface, large surface area compared to ordinary activated carbon, and the atomic structure is much more organized and compact [7]. Thus, application of carbon nanotubes to remove various harmful pollutants, especially heavy metals in aquatic environments has been shown to be more effective than any other adsorbent material [1].

Since its huge potential of application, a number of synthesis methods are rapidly developed to produce large amount of size-controlled CNTs for commercial applications. Some of those methods are chemical-based which has challenged to control the diameter of nanotubes, chirality, and wall number parameters [1], such as laser vaporization, arc discharge, pyrolysis, and plasma-enchanced or thermal chemical vapor deposition (CVD). For most of those strategies, however, complex process control, high reaction temperature, and long synthesis time are always needed [8]. Another well-known procedure, catalytic decomposition of hydrocarbons, also requires a complex purification process to get rid of the metal catalyst particles [9]. Those strategies had created the potential for a large scale production of carbon nanotubes becomes less efficient.

Different approaches of synthesis method have been introduced earlier. Since carbon nanotubes could be visualized as a sheet of graphite that has been warped to a tube [1], it is natural to come up with the imagination to prepare a direct synthesis by transforming the graphite into tubes with several strategies. Kang group [8], had conducted the convenient method to fabricate the wellcrystalline multiwalled carbon nanotubes (MWCNTs) at the ambient pressure and in the absence of catalyst called one-step water-assisted synthesis method. By using water, this method solved two problems which appeared in realizing the transformation of graphite into tube; The first one is how to obtain the suitable power which can make the graphite sheets crimp; the second one is how to wrap the honeycomb pattern back on top of itself and let the edges join by the C-C $\sigma$ bonds [8]. This study had demonstrated the potential production of carbon nanotubes with a more efficient way.
The development of green chemistry which is defined as utilization of the natural resources as a raw material to produce a certain chemical substance of compounds become hot topic of conducted research in several countries, particularly in Asia that have abundant sources of natural ingredients. Coconut shells which are produced from palm fruits processing in some tropical countries can be utilized as a carbon char that has economic value [10]. In relation with fabrication of carbon nanotubes, those combustion products of coconut shell which has a similar structure of graphite allotroph [11], has a huge opportunity to be utilized as a source of potential raw material for producing carbon nanotubes by the concept of green chemistry. One-step water assisted method that uses the calcining products of coconut shell as raw materials is proposed here as a first step to produce a sustainable, and environmentally friendly carbon nanotubes. Its application as an adsorbent of heavy metal ions $\mathrm{Pb}$ (II) was studied to determine its potential as an effective and natural-based adsorbent

\section{EXPERIMENTAL SECTION}

\section{Materials}

The coconut shell waste is taken from home industrial coconut in South Jakarta. Graphite flakes is made by burning the coconut shell at a temperature around $500-600{ }^{\circ} \mathrm{C}$ in a home-made furnace with minimum oxygen conditions. The main solution of $\mathrm{Pb}$ (II) $100 \mathrm{ppm}$ was prepared by dissolving 3.929 grams of $\mathrm{Pb}\left(\mathrm{NO}_{3}\right)^{2}$ that were purchased from Merck in $100 \mathrm{ml}$ of distilled water. Acetate buffer of $\mathrm{pH} 4,5,6$ and 7 are purchased from Dwinika Lab that will be used for adsorption test.

\section{Procedure \\ One-Step Water Assisted Synthesis}

The conducted stage of synthesis is quenching method that was developed by Kang et. al [8]. This method is selected because it is safe, inexpensive, and applicable to the industrial scale. First, 10 grams of graphite produced from burned coconut shell waste heated to $700{ }^{\circ} \mathrm{C}$ with the preparation of $50 \mathrm{ml}$ of cold distilled water at the same time. Once the temperature reached $700{ }^{\circ} \mathrm{C}$, the reddish graphite rapidly taken and immediately dipped in cold water then left for several hours. The heating performed in an oven for 24 hours at a temperature of $60^{\circ} \mathrm{C}$ to evaporate the water solvent. The synthesized carbons, which appeared as a black powder, was then characterized using, IR spectrophotometers, Scanning Electron Microscopy (SEM), and Transmission Electron Microscopy (TEM) 


\section{Adsorption Test of CNTs for $\mathrm{Pb}$ (II) lons}

The first step in this adsorption test is to prepare series of standard solution of $\mathrm{Pb}$ (II) with a concentration of $2,4,6,8$, and $10 \mathrm{ppm}$ by taking $0.2 ; 0.4 ; 0.6 ; 0.8 ; 1 \mathrm{ml}$ of mother liquor of $100 \mathrm{ppm} \mathrm{Pb}$ (II) respectively. Preparation of standard aimed to create a standard calibration curve by using AAS. The second step in this adsorption test is to do a variation of contact time at 10, 15, 20, 25 minutes. 0.5 grams of synthesized graphite powder of carbon sample taken then poured in four different glass beaker containing a solution of $\mathrm{Pb}$ (II) $5 \mathrm{ppm}$ The addition of a pH buffer performed to maintain the optimum $\mathrm{pH}$ at 5 . Adsorption test was conducted by stirring using a magnetic stirrer at the specified time the mixture is then filtered and the filtrate was analyzed by AAS. The third step is to test the adsorption in the various $\mathrm{pH}$ at $\mathrm{pH} 4,5,6$ and $7.40 \mathrm{ml}$ solution of $\mathrm{Pb}$ (II) $5 \mathrm{ppm}$ put in four different glass beakers then added a buffer to maintain the $\mathrm{pH}$ at a predetermined value Then $5 \mathrm{mg}$ powder of carbon sample inserted into glass beaker and stirring performed for 20 minutes. Filtration performed and the $\mathrm{Pb}$ concentration of the filtrate is determined by Atomic Absorption Spectroscopy (AAS).

\section{RESULT AND DISCUSSION}

Results regarding the information of the forming of our samples have been obtained by FTIR spectroscopy. Since Raman spectroscopy is a well-established tool for the investigation of the vibrational modes, there is no publication on the infrared active vibrations with results of comparable quality, the main obstacle being the poor sample quality of the raw materials produced [12]. Furthermore, infrared spectra for MWCNT samples are still lacking in literature.

Table 1. Carbon samples FTIR spectra.

\begin{tabular}{cclc}
\hline Peak & Centre $\left(\mathrm{cm}^{-1}\right)$ & \multicolumn{1}{c}{ Assignments } & Ref. \\
\hline 1 & 800 & $\begin{array}{l}\text { Smaller diameter of tube } \\
\text { D-band, disorder in sp }{ }^{2}-\end{array}$ & {$[13]$} \\
2 & 1438 & $\begin{array}{l}\text { hybridized carbon } \\
E_{2 g} \text { mode, stretching vibration }\end{array}$ & {$[12]$} \\
3 & 1580 & $\begin{array}{l}\text { of C-C group } \\
\text { O-H stretching vibration } \\
\text { modes }\end{array}$ & {$[13]$} \\
4 & $3000-3500$ & \\
\hline
\end{tabular}

The characterization results from our sample in Table 1 shows some absorption peaks that is rather varied. According to previous infrared spectra on CNTs [13] which states that smaller diameter tubes exhibit modes at lower wavenumbers, the low intensities mode that appear at $800 \mathrm{~cm}^{-1}$ correspondent to the formation of relatively smaller diameter of tube, which supported by the results of TEM. While the high intensity modes at 1438 $\mathrm{cm}^{-1}$ corresponds to modes generated by two previous studies, namely at $1430 \mathrm{~cm}^{-1}$ [12] and $1580 \mathrm{~cm}-1$ [8]. Based on those previous studies, this mode is responsible to $E_{2 g}$ mode of related to vibration of $s^{2}$-bonded carbon atoms in a two-dimensional (2D) hexagonal lattice [8]. While Branca group [12] reported that this mode may be reasonably assigned to the D-band, which is caused by induction of significant defects or disorder in these nanostructures. A weak peak in the range $3000-3500 \mathrm{~cm}^{-1}$ indicate the presence of $-\mathrm{OH}$ group that shows the tube still contains many impurities. In general, our spectra from the sample show the forming of carbon nanotubes from coconut shell flakes by the quenching method.
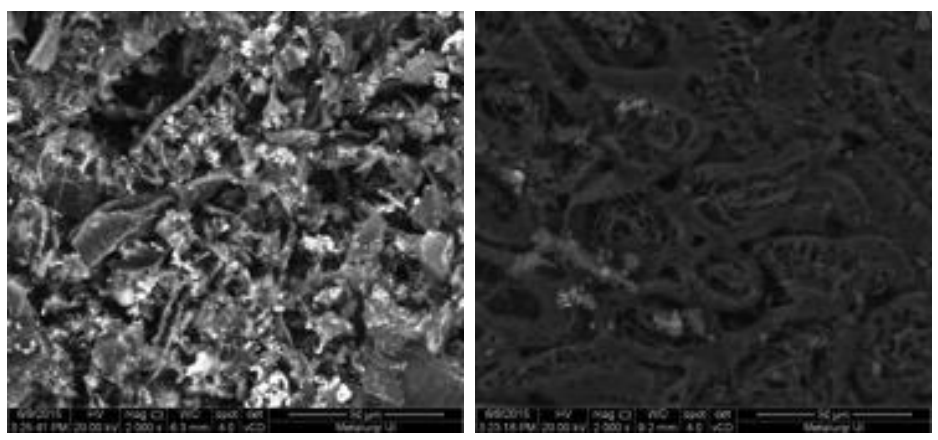

Figure 1. SEM image of the carbon samples investigated:

(a) quenched graphite,(b) untreated graphite

Characterization by SEM has also been carried out to obtain the micron size image of of the sample CNTs. Since SEM is a less accurate method determine the morphology of CNTs, SEM image of our sample showed a surface with irregular small fibers, agglomerated, and contained many impurities. This may be caused by several things. First, the water used as a medium for supporting the quenching process has not reached the appropriate temperature to alter the structure of a layer of graphite, which is 4 degrees. While, in previous studies [8], the water temperature of 0 degrees successfully produce carbon tubes with a quite good morphology. Second, the combustion process of coconut shell charcoal at the earlier step produces graphite flakes with less net of impurities. One thing is quite promising of these results is the SEM image of the sample quenched graphite show a different image with graphite samples which preferreably similar to marcoporous carbon. Figure [2] shows the potential formation of a new morphology of graphite compared with the untreated graphite which supported by results of TEM.

More representative and descriptive image of our samples was confirmed by TEM which are presented in Figure [3]. It can be clearly seen that samples similarly consist of single-walled nanotubes (SWNT) with a hollow internal channel bearing at the tip, rarely at an 


\section{ARTICLE IN PRESS}

Acta. Chim. Asiana., 2018, 1 (1), 6 - 10
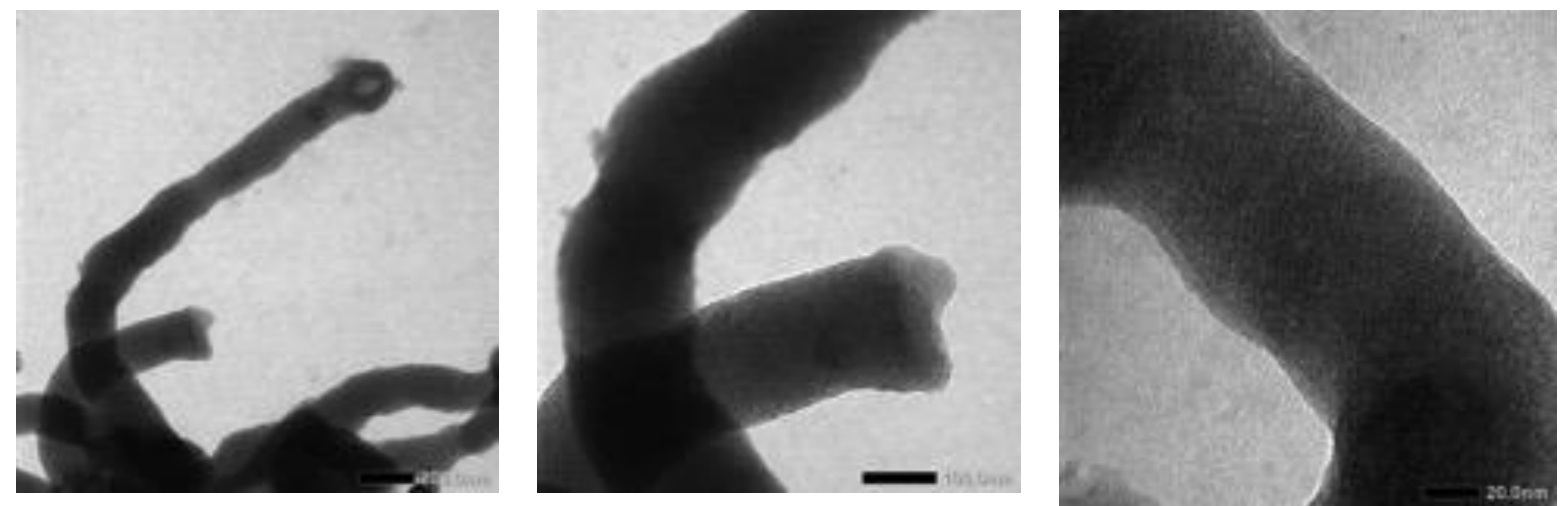

Figure 2. Representative TEM overviews of the carbon samples investigated: (a) $200 \mathrm{~nm}$ scaled, (b) $100 \mathrm{~nm}$ scaled (c) $20 \mathrm{~nm}$ scaled
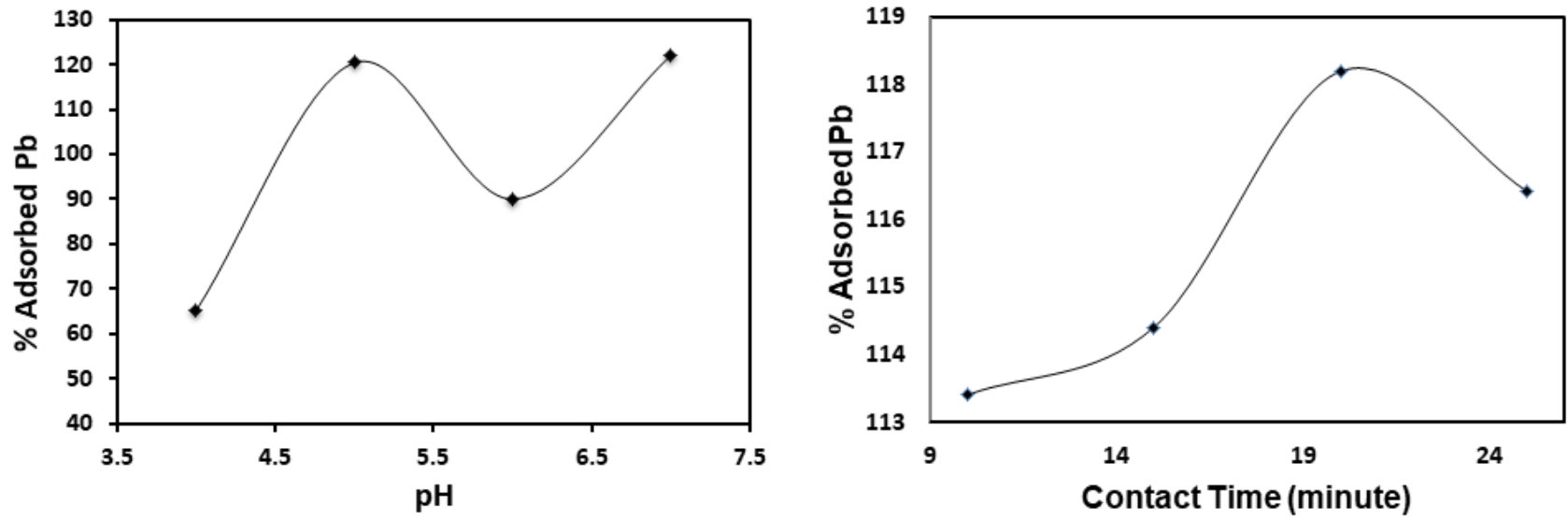

Figure 3. (a) $\mathrm{Pb}$ (II) adsorption test curve by samples with a pH variation; (b) $\mathrm{Pb}$ (II) adsorption test curve by samples with variation of contact time

intermediate length position. Averages over 17 different images of nanotube diameters provided an average inner diameter of approximately $123 \mathrm{~nm}$ respectively. The other studies conducted by Branca et al., [12], which synthesized multi-walled carbon nanotubes catalysed by $\mathrm{Ni}-\mathrm{KO}$ resulted in significant difference of outer diameter around $20.5 \mathrm{~nm}$. The similar method of this study that had been performed by Kang et al. [8], resulted the tubes with 30 and $50 \mathrm{~nm}$ for the inner and outer diameter respectively. Those results are reasonably different because of its pure and appropriate process which use pure mixed methane- $\mathrm{CO}_{2}$ gas [12] and pristine graphite rod [8]. Since our samples is still synthesized in a earlydeveloped method by combusting crude raw material such coconut shell, the nanotubes yield with a slightly wider inner diameter that is $120 \mathrm{~nm}$. However, this result told the promising production of nanostructured carbon tubes in a more green and convenient process.

In the adsorption test, $\mathrm{pH}$ variation are conducted to determine the optimum $\mathrm{pH}$ of $\mathrm{Pb}$ (II) ions adsorption by CNTs from $\mathrm{pH} \mathrm{4,} \mathrm{5,} \mathrm{6,} \mathrm{and} \mathrm{7.} \mathrm{The} \mathrm{results} \mathrm{in} \mathrm{Figure} \mathrm{[4]}$ show the amount of the adsorbed metal ion get into $60 \%$ in the lowest $\mathrm{pH}$. Then increase to reach the highest value of optimum $\mathrm{pH}$ which appropriate with the previous study [7] that is at $\mathrm{pH}$ 5. The adsorbed percent then decreased and twistly rised at the $\mathrm{pH} 7$.

At low $\mathrm{pH}$, increased amount of proton will lead to an enhancementof the positive charge on the surface of the tubes which will lead to electrostatically repel interaction with the ion metals $\mathrm{Pb}^{2+}$. This interaction will decrease the concentration of $\mathrm{Pb}$ adsorbed [7]. In contrast, $\mathrm{pH}$ increase causes the negative charge on tube surface, and it will more easily bind positively charged $\mathrm{Pb}^{2+}$ ions. The optimum $\mathrm{pH}$ for the absorption of $\mathrm{Pb}$ is at $\mathrm{pH} 5$ and it is proved in this experiment that the absorbed metal concentrations reached $120 \%$. At pH 6 , improvement the number of protons leads to formation of $\mathrm{OH}$ species which shall react with $\mathrm{Pb}^{2+}$ becomes $\mathrm{Pb}(\mathrm{OH})_{2}$ so that the $\mathrm{Pb}^{2+}$ species that is measured by AAS is also getting smaller. Adsorption equation goes according to the following equation [7] :

$$
\begin{aligned}
\mathrm{CNT}^{-} \mathrm{OH}_{2}^{+}+\mathrm{M}^{2+} & \leftrightarrow\left[\mathrm{CNT}-\mathrm{OHM}^{2+}\right]^{2+}+\mathrm{H}^{+} \\
\mathrm{CNT}^{-} \mathrm{O}^{-}+\mathrm{M}(\mathrm{OH})_{n}{ }^{2-\mathrm{n}} & \leftrightarrow\left[\mathrm{CNT}-\mathrm{O}^{-} \mathrm{M}(\mathrm{OH})_{n}^{2-n}\right]^{1-n}
\end{aligned}
$$


Adsorption test with a variation of the contact time respectively at $10,15,20$ and 25 minutes were conducted to determine the effect of contact time on the adsorption of measured concentrations. The effectiveness and the success of adsorption can be viewed from the curve which is directly proportional to the percent adsorbed by the contact time. The longer the contact time, the more the amount of $\mathrm{Pb}$ (II) which is absorbed. Interpretation of the data in Figure (5) shown increased concentrations of metal ions adsorbed from 10 minutes to 20 minutes, but in 25 minutes decreased. This may be due to the saturation in which the surface of the tubes has reached the maximum capacity of absorption of $\mathrm{Pb}$ so the adsorbed $\mathrm{Pb}(\mathrm{II})$ has been able to return off into the solution [1].

\section{CONCLUSION}

Since several methods of carbon nanotubes synthesis requires comples methods and strategies, a number of previous studies have been carried out to produce this advance nanomaterial in more convenient way. In this research, the synthesis of carbon nanotubes has been conducted from the charcoal of coconut shell waste with quenching method at a temperature of $700^{\circ} \mathrm{C}$. The results of the characterization of FTIR, SEM and TEM shows the formation of carbon tubes with irregular distribution and the average diameter is $123 \mathrm{~nm}$. Based on the adsorption test of $\mathrm{Pb}$ (II) by our synthesized samples, the optimum $\mathrm{pH}$ of $\mathrm{Pb}$ (II) absorption is $\mathrm{pH} 5$, accordance with a previous study by Ren et al. [7]. Adsorption test with variations of contact time showed concentrations of adsorbed $\mathrm{Pb}$ (II) directly proportional to the contact time, but may occur saturation at the time of more than 20 minutes.

\section{ACKNOWLEDGEMENTS}

This research was financially supported by Hibah PKM Dikti Kementerian Pendidikan Nasional Republik Indonesia Tahun Anggaran 2015. Contract No.0074/E5.3/KPM/2015. The author would also like to thank the Department of Chemistry, Faculty of Mathematics and Natural Sciences and Department of Metallurgy and Material, Faculty of Engineering, Universitas Indonesia for the provision of laboratory facilities; and Department of Chemistry, Faculty of Mathematics and Natural Sciences, Universitas Gajah Mada, Yogyakarta for the TEM instrument.

\section{REFERENCES}

1. Rao, G.P., C. Lu, and F. Su. (2007). Sorption of divalent metal ions from aqueous solution by carbon nanotubes: A Review. Sep. and Pur. Tech., 58, 224231.
2. Sekar, M., V. Sakthi, S. Rengaraj, (2004) Kinetics equilibrium adsorption study of lead(II) onto activated carbon prepared from coconut shell, J. Colloid Interface Sci, 279 : 307-313.

3. Biskup, B., and B. Subotic. (2004) .Removal of heavy metal ions from solutions using zeolites. III. Influence of sodium ion concentration in the liquid phase on the kinetics of exchange processes between cadmium ions from solution and sodium ions from zeolite, Sep. Sci. Tech. 39 : 925-940

4. Arias, M., M.T. Barral, J.C. Mejuto, (2002) Enhancement of coper and cadmium adsorption on kaolin by the presence of humic acids, Chemosphere $48: 1081-1088$

5. lijima, S. (1991), Helical microtubules of graphitic carbon. Nature, 354, 56-58.

6. Haddon, R.C. (2002). Chemistry of single-walled carbon nanotubes, Acc. Chem. Res. 35 977-1113.

7. Ren, X., C. Chen, M. Nagatsu, and X. Wang. (2010). Carbon nanotubes as adsorbents in environmental pollution management: a review. Chem. Eng. Jour. 16, 226-242

8. Kang, Z., Enbo W., Lei G., Suoyuan L., Min J., Changwen H., and Lin X. (2003). One-Step waterassisted synthesis of high-quality carbon nanotubes directly from graphite. J. Am. Chem. Soc. 125 : 13652-13653

9. Zhu, H.W., Xu, C.L., Wu, D.H., Wei, B.Q., Vajtai, R., Ajayan, P.M. (2002). Direct synthesis of long singlewalled carbon nanotube strands. Science, 296, 884886

10. Pambayun, G. S, R.Y.E. Yulianto, M. Rachimoellah, and E.M.M. Putri. (2013). Pembuatan karbon aktif dari arang tempurung kelapa dengan aktivator $\mathrm{ZnCl}_{2}$ dan $\mathrm{Na}_{2} \mathrm{CO}_{3}$ sebagai adsorben untuk mengurangi kadar fenol dalam air limbah. Jurnal Teknik POMITS

11. Rampe, M.J., B. Setiaji, W. Trisunaryanti, Triyono. (2011). Fabrication and characterization of carbon composite from coconut shell carbon. Indones. J. Chem., 11 (2), $124-130$

12. Branca, C. C. Corsaro, F. Frusteri, V. Magazu, A.Mangione, F.Migliardo , U. Wanderlingha. (2004) Structural and vibrational properties of carbon nanotubes by TEM and infrared spectroscopy. Diamond and Related Materials. 13 : 1249-1253

13. Chiang, I.W., B.E. Brinson, R.E. Smalley, J.L. Margrave, R.H. Hauge, (2001). Purification and characterization of single-wall carbon nanotubes. J. Phys. Chem. B 105:s 1157 2(1): 2337-3539 